Research article

\title{
Agrokor: Political Aspects of the Crisis of Croatia's Biggest Conglomerate
}

\author{
M. Zubovic \\ Diplomatic Academy, Ministry of Foreign Affairs of the Russian Federation \\ Ostozhenka str., 53/2, build. 1, Moscow, Russian Federation, 119992
}

\begin{abstract}
When the conglomerate Agrokor, the biggest privately-owned company in Croatia and the Balkans, found itself on the verge of bankruptcy in 2017 due to its outstanding debts, the whole Croatian economy was under a threat of collapse. Since Agrokor accounts for $15 \%$ of the country's economy and employs approximately 60000 people, the situation was particularly alarming for the government, which decided to intervene by starting the bailout process. Taking into consideration the fact that Agrokor's biggest creditors were Russian banks Sberbank and VTB, the crisis also had certain political implications. In the midst of the critical situation, the Croatian leadership had to coordinate the country's domestic and global policies, attempting to find a common ground with Russia and surmount the crisis.
\end{abstract}

Keywords: Agrokor, Croatia, Croatian-Russian relations, foreign policy, economy

\section{Introduction}

Successful economic development is of crucial importance to every modern country, but even more so is the maintenance of its economic stability. Although the economy of each individual country is susceptible to changes and fluctuations on the market, bigger and more developed economies have an easier time dealing with such circumstances than smaller ones. Belonging to the latter category, Republic of Croatia was faced with serious challenges when the country's biggest company, Agrokor, found itself on the verge of bankruptcy and heavily indebted to foreign banks - above all, to Russia's Sberbank and VTB.

The crisis obtained a political dimension when Croatian government decided to interfere in order to prevent the company - and at the same time, national economy from crashing. Soon afterwards, various issues related to Croatian domestic and foreign policies surfaced, what undoubtedly prolonged and further complicated the bailing out process.

In the first part of the article, a brief history of Agrokor and its development will be given. Special emphasis will be put on the way how the business in the conglomerate was handled and how Ivica Todoric, Agrokor's former owner, spread the company's area of influence. Moreover, this part of the article will cover how the crisis began, as

\section{Zubovic M., 2019.}

This work is licensed under a Creative Commons Attribution 4.0 International License https://creativecommons.org/licenses/by/4.0/ 
well as what measures Croatian government had undertaken in order to prevent the conglomerate from collapsing.

In order to fully depict and understand the proportions of the crisis and the way it influenced Croatia's foreign policy and relations with Russian Federation, the second part of the article will give an overview of the turmoil that Agrokor case caused in the Croatian domestic policy and political scene. It will reflect on the consequences these events have had on the overall bailout process.

The final part of the work will focus on the relations between Croatia and Russia. Due to the fact that Russian banks were Agrokor's biggest creditors, it does not surprise that the situation affected the countries' relations and that the political dimension was all the more emphasized.

Conclusion will cover all the main points and ideas presented in the article, as well as provide additional analysis of the situation, with emphasis on the foreign policy sector.

\section{Agrokor: history and development of the biggest conglomerate in the Balkans}

Agrokor's history dates back to 1976 when Ivica Todoric founded the agricultural business specialized in floristry. This small, family-owned company soon started selling flowers all over the former Yugoslavia, simultaneously earning returns on investment, which then led to the expansion of the business onto wheat and oils. As a result, the company generated higher turnover and ensured easier access to finance. In 1989, Todoric registered his business under the name "Agrokor", stating its specialization in the production, distribution and trade of flowers, as well as trade in oilseed and cereals [1].

Over the course of time Agrokor's expansion continued, and even though he never openly expressed his political adherence to any political party, Ivica Todoric has always been in close contact with the political elite, what enabled him an easy access to various enterprises offered for sale by the State Privatization Fund. Moreover, Todoric was also in a good position to receive bank loans in order to purchase those enterprises. In a few years, he bought several companies, but the acquisition of a retail chain "Konzum" in 1994 was a stepping stone in Todoric's business career, granting him access to commercial property, as well as a big share of the market [1].

Agrokor's expansion did not stop there. Soon, the company started to spread all over the region, taking control over production and retail markets in Serbia, Hungary, Bosnia and Herzegovina, as well as Slovenia. Aside from the spheres of retail, agriculture and food production, Todoric soon expanded his business onto other areas he considered profitable, such as tourism, healthcare and the energy sector. However, the basis of this business expansion was the expensive debt accumulation, and the way of securing the majority of funding included selling bonds on international markets, as well as obtaining loans from commercial banks [1].

In the period between 2005 and 2007 [2], through the implementation of the aforementioned principle of debt accumulation, Todoric purchased a number of Croatian companies, such as PIK Vrbovec, Belje, Tisak, etc., and also expanded the retail chain 
"Konzum" to wholesale, simultaneously increasing the conglomerate's vertical integration and area of influence [2]. The biggest transaction in the history of the region took place in 2014, when Agrokor purchased Slovenian retail chain "Mercator" for 544 million euros [3]. Considering the fact the company was already heavily financially burdened, this particular purchase was a step too far and the beginning of Agrokor's collapse [1].

Due to the fact the conglomerate's business strategies had been kept private over the years, the public was first informed of the problems in Agrokor no sooner than 2017, when the agency Moody's downgraded the company's rating from B2 to B3, and upgraded the bankrupcy rate from B1-PD to B3-PD [4]. This stirred up the rumours about its potential collapse, simultaneously provoking reactions from stakeholders, general public and politicians alike [5].

With approx. 60000 employees and annual sales of 6.5 billion euros, Agrokor remains the largest conglomerate not only in Croatia, but whole Southeast Europe [6]. The company's income makes up 15\% of Croatian economy [7] and its collapse would have destroyed not only the country's economy, but also negatively influenced the overall economic stability in the region. For this reason, the Croatian government had to interfere by introducing a special legislation in order to overcome the conglomerate's financial problems, passing a special law on 6 April 2017 [8], the so-called "Lex Agrokor" [9]. However, the situation in Agrokor had unravelled a number of problems related not only to Croatian economy, but also the country's domestic and foreign policies.

\section{Effects of the Agrokor crisi on the Croatian domestic policy}

The crisis and the collapse of Agrokor is the first case in the history of Croatia as an independent country which can be considered as "too-big-to-fail" (TBTF) case [10]. Companies, belonging to this category, are characterized by their systematic importance for the whole country due to their size, area of influnce, number of employees, etc. Their potential failure carries the risk of immense disruptions to the overall financial system [11].

As the crisis in Agrokor continued to worsen and the risk of bankrupcy increased, Ivica Todoric turned to the Croatian government, secretly meeting with the Prime Minister Andrej Plenkovic and the ministers in March 2017 [12]. The potential government bailout was discussed, which also presupposed a loan from the state development bank (The Croatian Bank for Reconstruction and Development) [1]. This period was the beginning of a turnmoil and various conflicts in the leading coalition of the Croatian government, a centrist MOST party and HDZ (Croatian Democratic Union), revolving around the Minister of Finance Zdravko Maric. As a former Agrokor employee, Maric was accused of conflict of interest and MOST party demanded him to be excluded from the bailout process [12]. Simultaneously, the government started preparing the aforementioned "Lex Agrokor", dismissing Ivica Todoric of his duty and appointing emergency administration [13]. The law is in fact an "EA Act" (Act on 
Extraordinary Administration Proceedings in Companies of Systemic Importance for the Republic of Croatia), which determines the framework for an extraordinary restructuring proceedings, intended for companies considered to be of systematic importance for the country's economy [14].

The situation in the Croatian Parliament escalated on April 27, 2017, when Prime Minister Plenkovic dismissed three MOST ministers, after they backed a no-confidence vote against minister Maric's and his involvement in the Agrokor case. Soon afterwards, the president of Parliament and MOST Bozo Petrov declared the party's exit from the coalition, stating they were no longer a part of the government which protects criminal actions and corruption in the country's largest conglomerate [12]. Eventually, minister Maric managed to keep his post after a very narrow parliamentary majority vote. Had it not been that way, Croatia would have been facing the second snap general elections in less than one year [15].

It was not long before the special Agrokor law became a subject of another affair, this time the one associated with the group of experts who were working on the it, including the Croatian Minister of Economy and vice-prime minister Martina Dalic. The affair was referred to as "the Hotmail scandal" and it revolved around the email correspondance between Dalic and the group, the details of which surfaced in the Croatian media. Via her personal Hotmail account, Dalic co-operated with a circle of lawyers, consultants and businessmen, coming up with the text of the "Lex Agrokor" before it was approved by the Croatian Parliament and without the Croatian public being informed of their activities and involvement in the process [13]. Moreover, the correspondence shows that Dalic and the group deliberately deceived the public regarding the actual state of affairs in Agrokor, simutaneously using their positions to make profit in Agrokor case [16]. Once again, the affair stirred up serious turbulence on the Croatian political scene, especially after it became clear that the PM Plenkovic was fully aware of all the details of the corrupted process [17]. Eventually, faced with allegations against her, vice-prime minister Dalic resigned, but prime minister Plenkovic refused to take on any responsibility and continues to do so up to this date [18].

\section{Agrokor and Croatian-Russian relations}

The crisis in Agrokor affected the relations between Croatia and Russia, economic and political ones alike, due to the fact that two Russian banks - Sberbank and VTB are the conglomerate's largest creditors [19]. Back in 2014, already deep in debt, Agrokor had trouble finding Western investors who were eager to lend money on acceptable terms, which is why Todoric soon turned to Russian banks. At the time, Sberbank had started its expansion in South East Europe, and agreed on a loan of 600 million euros with lower interest rates. Moreover, Agrokor took out another loan (300 million euros) from another Russian bank, VTB, and over time, the conglomerate's debt reached the sum of over 1.1 billion euros, resulting in the fact that the debt to Russian banks "accounted for $53 \%$ percent of the overall debt to banks" [1].

Unsurprisingly, this took a toll on the development of prosperous international relations between the two countries, which have already had a "status quo" for a number of years. After it joined the NATO and the EU, Croatia directed its foreign policy mostly 
in the European direction, simultaneously "freezing" relations with Russia, the best evidence of which is the absence of presidential contacts between the two countries for almost 10 years (2000-2010) [20], as well as the fact that Croatia did not have its ambassador in Moscow for 2 years [21].

Even though the situation in Agrokor was mostly approached and observed from an economic perspective, it undoubtedly carries a lot more political weight than it might seem at first. When Anvar Azimov, Russian ambassador in Croatia, in 2017 stated that Russian banks would no longer credit Agrokor and that Russia expects the debt to be fully returned [22], it became obvious that politics is also greatly involved in Agrokor case and that the outcome of the situation was to have certain consequences on the relations between Croatia and Russia.

Along with the aforementioned turmoil on the Croatian political scene, negotiations between Agrokor's emergency administration and Russian banks have also gone through turbulent periods. The situation hit a crisis point when Sberbank announced they were no longer participating in the negotiation process and were to file suit against Agrokor [23] for falsifying its financial reports over the years [24], but it was eventually resolved in the spring 2018. The bank managed to reach an agreement with the new president of emergency administration, Fabris Perusko, and ensure a deal which would ensure their claims are met in the Agrokor case [25]. In the summer of 2018 a settlement between Agrokor creditors and emergency administration was eventually achieved, according to which Sberbank and VTB jointly obtained 47\% stake in the new company [26], called Fortenova Grupa as of April 1, 2019 [27].

However, the fact that the most important company in Croatian economy is now under Russian control changed the political and geopolitical situation in the region to a great extent. In the light of tense relations between Russia and the West, such active presence of Russian banks in the economy of one NATO and the EU member state is frowned upon by the Western countries. Moreover, Croatia is one of the strongest allies of the United States in the Balkans [28], which is another reason due to which Russia's actions are perceived as a destabilizing factor in this part of Europe.

Regarding the aforementioned stagnation in the Croatian-Russian international relations, a relatively important step in the right direction was made in October 2017, when Croatian president Kolinda Grabar-Kitarovic paid an official visit to Russia, where she took part in the Russian-Croatian Economic Forum in Moscow and held meetings with a number of highly positioned Russian diplomats, Prime Minister Medvedev and president Putin included [28]. However, it can be safely said that the main reason behind Kitarovic's visit was the ongoing situation in Agrokor, which was discussed in Sochi with president Putin and Herman Gref, Sberbank's CEO [29]. Even though the Croatian president expressed her willingness to mediate in the negotiation process and help improve the situation [24], it needs to be emphasized that the main decisions regarding Croatian foreign policy are not made by the president, but Prime Minister and the government. The fact that Prime Minister Plenkovic, during his official visit to Ukraine, openly expressed Croatia's support regarding the "peaceful reintegration" of Crimean territory and readiness to advise the Ukrainian leadership on the subject [30], provoked a serious reaction from the Kremlin. This is just one of the examples which illustrate various 
inconsistencies and contradictions within Croatia's domestic political situation, and which are, in turn, negatively reflected on its foreign policy.

However, the Agrokor case, and the deal which was eventually made, undoubtedly gave Russia political and strategic advantage in the Balkans. In the light of European sanctions against Russia, two of Russia's national banks would now hold majority ownership in the economy of a European country, which serves as a good basis for the spread of Russian influence in the region.

\section{Conclusion}

The fall of Croatian's biggest company affected and threatened not only the country's economic, but also political stability. What started as a solely economic problem, soon turned out to be politically influenced and aspected on various levels. Due to heavy indebtedness to foreign banks - especially Russian Sberbank and VTB - and a risk of bankruptcy, Agrokor's former owner and CEO Ivica Todoric handed the conglomerate into the hands of the government, in the hope of bailing out and rescuing his struggling business.

However, this move only unravelled a number of problems Croatia is facing nowadays, related to domestic and foreign policies alike. One of the biggest ones is by far high level of corruption and lack of transparency in handling the country's affairs. Agrokor case had almost caused the fall of Croatian government, and in the foreign policy sector, it underlined ongoing disagreements and inconsistencies between the president and the government - issues which complicate and prevent the successful development of the country's international relations to a great extent.

The situation in Agrokor had shaken the stagnating relations between Croatia and Russia. Even though the official meetings of the presidents of the two countries in nearly a decade is certainly an improvement in the bilateral relations, the fact that the issue of Croatian indebtedness to Sberbank and VTB was discussed on the highest diplomatic level speaks for itself about the consequences Agrokor case could have had for the relations between the countries. Eventually, after years of negotiations and turmoil, the situation in Agrokor was resolved and a settlement achieved. However, it cannot be denied that the whole process could have been much faster and less damaging for Croatia's economy and foreign policy, if the domestic policy had been handled more transparently.

The outcome of the Agrokor crisis is a new company, Fortenova Grupa, as well as a new owner structure, in which Russian banks hold over $50 \%$ share. From a political and strategic perspective, this gives Russia an opportunity to spread and strengthen its influence in the Balkans, especially given the fact it now plays a crucial role in the economy of an EU and a NATO country. The West perceives this as a troublesome factor, however, Russian banks had every right to ensure their claims are fulfilled. Another question which arises in this regard is why the Western banks and institutions did not offer more adequate help in the Agrokor crisis. Either way, Agrokor scenario should be a good lesson to Croatian leadership and a sign to pay more attention to the various problems lying in the core of the country's domestic policy, as well as to work more on the improvement of the relations with Russia, now so actively present in the country's economic and political scene. 


\section{REFERENCES}

[1] Klepo M., Bićanić I., Ivanković Ž. The Case of Agrokor: The Crisis of the Largest Croatian Company. Zagreb: Friedrich-Ebert-Stiftung, Regionalni ured za Hrvatsku i Sloveniju, Studeni; 2017.

[2] Petrović N. Agrokor: Između političkog kapitalizma i ekonomskog liberalizma. Čengić D. (ed.). Kapitalizam i socijalna integracija. Zagreb: Institut društvenih znanosti Ivo Pilar; 2008: 89111 (In Cro.).

[3] Jutarnji List. Kronologija stvaranja velikog koncerna: Znate li koje je godine osnovan Agrokor i koliko je koštala najveća transakcija u povijesti regije? Available from: https://www.jutarnji.hr/ vijesti/hrvatska/kronologija-stvaranja-velikog-koncerna-znate-li-koje-je-godine-osnovan-agrokori-koliko-je-kostala-najveca-transakcija-u-povijesti-regije/5776463/. Accessed: 09.04.2019 (In Cro.).

[4] Od pada Vlade do ulaska ruskih banaka u Agrokor: Godina velikih turbulencija u najvećem hrvatskom koncernu. Dnevnik.hr. 10.05.2019. Available from: https://nevnik.hr/vijesti/hrvatska/ kronologija-krize-u-agrokoru-godina-velikih-turbulencija---513160.html. Accessed: 09.04.2019 (In Cro.).

[5] Njavro M, Juračak J, Čop T. Agrokor Case: The Recent Past and The Uncertain Future of The Big Agribusiness Conglomerate In Croatia. Proceedings in Food System Dynamics. 09.07.2018. Available from: http://centmapress.ilb.unibonn.de/ojs/index.php/proceedings/article/view/1804. Accessed: 09.04.2019.

[6] Dobrić D. Zaboravljeni Agrokor: Što se zbiva s najvećim koncernom u regiji? DW. 27.08.2018. Available from: https://www.dw.com/hr/zaboravljeni-agrokor-\%C5\%A1to-se-zbiva-s-najve\% C4\%87im-koncernom-u-regiji/a-45239736. Accessed: 09.04.2019 (In Cro.).

[7] Karasik T. If Croatia Joins the Eurozone, It Would Give Russia Its Greatest Weapon in Europe. Euronews.com. 22.01.2019. Available from: https://www.euronews.com/2019/01/22/if-croatiajoins-the-eurozone-it-would-give-russia-its-greatest-weapon-in-europe-view. Accessed: 10.04.2019.

[8] Hawthorn D., Thompson A. Re Agrokor DD: An Extraordinary Foreign Proceeding, but not too Extraordinary for Recognition under the Cross-Border Insolvency Regulations 2006. Corporate Rescue and Insolvency. 2018; 11 (1): (6-9). Available from: https://www.michelmores.com/ sites/default/files/ReAgrokorDD.pdf. Accessed: 09.04.2019.

[9] Lex Agrokor stupio na snagu, pročitajte cijeli tekst zakona. Dnevnik.hr. Available from: https://dnevnik.hr/vijesti/hrvatska/lex-agrokor-stupio-na-snagu-procitajte-cijeli-tekst-zakona--472538.html. Accessed: 09.04.2019 (In Cro.).

[10] Rubinić I., Bodul D. Regulation of the "Too-Big-To-Fail" Entities in the Republic of Croatia. Ekonomski pregled. 2018; 69 (3): 298-321. Available from: https://hrcak.srce.hr/202520. Accessed: 09.04.2019.

[11] Labonte M. Systemically Important or “Too Big to Fail” Financial Institutions. Washington, DC: Congressional Research Service; 2018.

[12] Agrokor: Kronologija krize koja je obilježila 2017. Poslovni dnevnik. Available from: http://www.poslovni.hr/hrvatska/agrokor-kronologija-krize-koja-je-obiljezila-2017-335588. Accessed: 09.04.2019 (In Cro.).

[13] Vale G. Croatia, from the Collapse of Agrokor to the Hotmail Scandal. Osservatorio Balcani e Caucaso Transeuropa. 07.06.2018. Available from: https://www.balcanicaucaso.org/eng/ Areas/Croatia/Croatia-from-the-collapse-of-Agrokor-to-the-Hotmail-scandal-188116. Accessed: 15.04.2019.

[14] American College of Investment Council. Lex Agrokor. Available from: https:/www.aciclaw.org/ news/2018/lex-agrokor. Accessed: 15.40.2019.

[15] Croatia's Largest Business Group's Collapse Threatens Government Stability. Agencia EFE. 19.05.2017. Available from: https://www.efe.com/efe/english/business/croatia-s-largest-businessgroup-collapse-threatens-government-stability/50000265-3271424. Accessed: 14.40.2019. 
[16] Ćimić I. Afera Hotmail pokazala je sanaderovsko lice Plenkovićeva HDZ-a. Index.hr. 31.12.2018. Available from: https://www.index.hr/vijesti/clanak/afera-hotmail-pokazala-jesanaderovsko-lice-plenkoviceva-hdza/2052817.aspx. Accessed: 17.04.2019. (In Cro.).

[17] Pauček Šljivak M. Reakcije političara na Dalićkin iskaz u Uskoku: "Plenković mora otići". Index.hr. 23.08.2018. Available from: https://www.index.hr/vijesti/clanak/reakcije-politicara-nadalickin-iskaz-u-uskoku-plenkovic-mora-otici/2019320.aspx. Accessed: 17.04.2019. (In Cro.).

[18] Ćimić I. Agrokor je bio i ostao sramotno lice Hrvatske. Index.hr. 05.07.2018. Available from: https://www.index.hr/vijesti/clanak/agrokor-je-bio-i-ostao-sramotno-lice-hrvatske/2008855.aspx. Accessed: 17.04.2019 (In Cro.).

[19] Creditors Approve Agrokor Debt Settlement Deal. Reuters. 04.07.2018. Available from: https://www.reuters.com/article/us-croatia-agrokor/creditors-approve-agrokor-debt-settlementdeal-idUSKBN1JU1XX. Accessed: 17.04.2019.

[20] Orlik I.I. The Main Trends in Relations between Russia and the Central and Eastern Europe Countries. Moscow: Institut ekonomiki RAN; 2015: 381- 401 (In Russ.).

[21] Croatia Turns Face to Russia. Kommersant. 18.10.2017. Available from: https://www.kommersant.ru/doc/3441596. Accessed: 07.05.2019 (In Russ.).

[22] Duka Z. Anvar Azimov: Agrokor neće više dobivati ruske kredite, ne zanima nas ulazak u vlasničku strukturu te tvrtke. Novilist.hr. 10.02.2017. Available from: http://www.novilist.hr/ Vijesti/Hrvatska/Anvar-Azimov-Agrokor-nece-vise-dobivati-ruske-kredite-ne-zanima-nas-ulazaku-vlasnicku-strukturu-te-tvrtke. Accessed: 07.05.2019 (In Cro.).

[23] Sberbank popušta!? Predsjednik Uprave moćne ruske banke progovorio o dugu Agrokora: 'Bili smo ignorirani, ali sada svjedočimo promjeni situacije'. Jutarnji.hr. 22.12.2017. Available from: https://www.jutarnji.hr/biznis/sberbank-popusta-predsjednik-uprave-mocne-ruske-bankeprogovorio-o-dugu-agrokora-bili-smo-ignorirani-ali-sada-svjedocimo-promjeni-situacije/6869172/. Accessed: 07.05.2019 (In Cro.).

[24] Ruski mediji otkrili s kim su se Grabar Kitarović i Dinko Cvitan susreli. Tportal.hr. 19.10.2017. Available from: https://www.tportal.hr/biznis/clanak/posjet-rusiji-u-znaku-agrokora-otkrivenos-kim-se-osim-s-putinom-susrela-predsjednica-20171019. Accessed: 08.05.2019 (In Cro.).

[25] Agrokor postigao dogovor sa Sberbankom: Izvanredni povjerenik potvrdio: Ruska banka će povući tužbe, a Agrokor će priznati njezine tražbine. Jutarnji.hr. 21.03.2018. Available from: https://www.jutarnji.hr/biznis/tvrtke/agrokor-postigao-dogovor-sa-sberbankom-izvanrednipovjerenik-potvrdio-ruska-banka-ce-povuci-tuzbe-a-agrokor-ce-priznati-njezine-trazbine/7155426/. Accessed: 08.05.2019 (In Cro.).

[26] Vladisavljević A. Creditors Reach Settlement with Croatia's Troubled Agrokor. Balkan Isnight. 19.06.2018. Available from: https://balkaninsight.com/2018/06/19/agrokor-s-creditors-supportedthe-settlement-06-19-2018/. Accessed: 07.05.2019.

[27] Agrokor od danas posluje kao Fortenova grupa, evo što to točno znači. Tportal.hr. 01.04.2019. Available from: https:/www.tportal.hr/biznis/clanak/agrokor-od-danas-posluje-kao-fortenovagrupa-evo-sto-to-tocno-znaci-foto-20190401. Accessed: 08.05.2019 (In Cro.).

[28] Samorukov M. Croatia: Moscow's New Ally, or a Brief Fling? Carnegie Moscow center. 27.10.2017. Available from: https://carnegie.ru/commentary/73562. Accessed: 10.05.2019.

[29] Russia, Croatia Leaders Discussed Agrokor Debts; Talks to Continue. Reuters. 18.10.2017. Available from: https:/www.reuters.com/article/russia-croatia-agrokor/russia-croatia-leadersdiscussed-agrokor-debts-talks-to-continue-idUSR4N1MM023. Accessed: 07.05.2019.

[30] Vurušić V. Grmljavina iz Kremlja nakon Plenkovićeva prijedloga za posjeta Ukrajini: 'Ozbiljno smo zabrinuti, bilo bi vam bolje da se bavite vlastitim problemima'. Vijesti. 22.11.2016. Available from: https://www.jutarnji.hr/vijesti/hrvatska/grmljavina-iz-kremlja-nakon-plenkoviceva-prijedlogaza-posjeta-ukrajini-ozbiljno-smo-zabrinuti-bilo-bi-vam-bolje-da-se-bavite-vlastitim-problemima/ 5295403/. Accessed: 11.05.2019 (In Cro.). 


\title{
Article history:
}

The article was submitted on 16.05.2019.

The article was accepted on 26.06.2019.

\section{Агрокор: политические аспекты кризиса в крупнейшем хорватском концерне}

\author{
М. Зубович \\ Дипломатическая академия МИД России \\ Остоженка 53/2, стр. 1, Москва, Россия, 119992
}

\begin{abstract}
Аннотация. Когда концерн Agrokor, крупнейшая частная компания в Хорватии и на Балканах, оказался в 2017 году на грани банкротства из-за большой задолженности, вся экономика Хорватии оказалась под угрозой краха. Поскольку на Агрокор приходится 15\% экономики страны и компания предоставляет работу примерно для 60000 человек, ситуация была особенно тревожной, и правительство Хорватии решило вмешаться. Учитывая тот факт, что крупнейшими кредиторами Агрокора были российские банки Сбербанк и ВТБ, кризис в целом приобрел и политический характер, в котором хорватское руководство должно было согласовать внутреннюю политику страны с внешней и стремиться найти общий язык с Россией, для того чтобы преодолеть множество трудностей.
\end{abstract}

Ключевые слова: Агрокор, Хорватия, хорватско-российские отношения, внешняя политика, экономика

\section{История статьи:}

Статья поступила в редакцию 16.05.2019.

Статья принята к публикации 26.06.2019.

\section{Информация об авторе:}

Зубович Марта - аспирантка кафедры политологии и политической философии Дипломатической академии МИД России (ORCID ID: 0000-0002-3829-306X) (e-mail: zubovicmarta@gmail.com).

\section{Information about the author:}

Marta Zubovic — PhD Student of the Department of Politology and Political Philosophy, Diplomatic Academy, Ministry of Foreign Affairs of the Russian Federation (Russian Federation) (ORCID ID: 0000-0002-3829-306X) (e-mail: zubovicmarta@gmail.com).

\section{Для цитирования:}

Zubovic M. Agrokor: Political Aspects of the Crisis of Croatia's Biggest Conglomerate // Вестник Российского университета дружбы народов. Серия: Политология. 2019. Т. 21. № 3. С. 430438. DOI: $10.22363 / 2313-1438-2019-21-3-430-438$.

\section{For citation:}

Zubovic M. Agrokor: Political Aspects of the Crisis of Croatia's Biggest Conglomerate. RUDN Journal of Political Science. 2019; 21 (3): 430-438. DOI: 10.22363/2313-1438-2019-21-3430-438. 